\title{
Mineralogical and Geochemical Characteristics of Hydrothermal Minerals Collected from Hydrothermal Vent Fields in the Southern Mariana Spreading Center
}

\author{
Kei Ikehata, Ryohei Suzuki, Kazuhiko Shimada, Jun-ichiro Ishibashi, \\ and Tetsuro Urabe
}

\begin{abstract}
Seafloor hydrothermal mineralization of four active hydrothermal fields (Snail, Yamanaka, Archaean and Pika sites) in the Southern Mariana Trough was investigated to clarify the mineralogical and geochemical characteristics of the hydrothermal minerals. The Snail site and the Yamanaka site are located on the crest of the backarc spreading ridge (on-axis). The Pika site sits atop an off-axial volcano, $4.9 \mathrm{~km}$ distant from the spreading axis, while the Archaean site sits on the flank of the spreading ridge, about $1.5 \mathrm{~km}$ distant from the axis. In the four hydrothermal sites, chimney and mound sulfides are composed mainly of pyrite, marcasite, sphalerite and chalcopyrite. Conduits and interstices of these sulfide minerals are filled with late barite and anhydrite. Mineralizations of off-axial hydrothermal fields have mineralogical and geochemical signatures (Fe-rich and low $\mathrm{f}_{\mathrm{S} 2}$ condition) similar to those of mineralizations at sediment-free mid-ocean ridge settings. By contrast, mineralizations of on-axial sites show distinctly $\mathrm{Zn}$ and $\mathrm{Pb}$-rich (high $\mathrm{f}_{\mathrm{S} 2}$ condition) signatures similar to those found in arc or rifting settings. Sulfur isotopic compositions of collected sulfide minerals show a similar diversity with a mid-ocean ridge range for the off-axial sites and an island-arc range for the on-axial sites. These isotopic signatures could be explained by varying proportions of magmatic sulfur leached from the underlying volcanic rocks and reduced seawater sulfates.
\end{abstract}

Keywords

Seafloor hydrothermal mineralization • Southern Mariana Trough $\bullet$ Sulfate mineral $•$ Sulfide mineral

K. Ikehata $(\bowtie)$

Faculty of Life and Environmental Sciences, University of Tsukuba, Ibaraki, Japan

e-mail: ikkei@geol.tsukuba.ac.jp

R. Suzuki • K. Shimada • J.-i. Ishibashi

Faculty of Sciences, Kyushu University, Fukuoka, Japan

T. Urabe

Department of Earth and Planetary Science, The University

of Tokyo, Tokyo, Japan

\subsection{Introduction}

Modern seafloor hydrothermal mineralization is mainly found in three types of environments: at mid-ocean ridges, at intraoceanic arc-backarc systems such as the Mariana Trough, and at intracontinental arc-backarc systems such as the Okinawa Trough (Herzig and Hannington 1995; Herzig et al. 2002). Seafloor massive sulfides formed in the subductionrelated arc and backarc environments have attracted the attention of economic geologists since these hydrothermal fields are considered to be modern analogues of volcanogenic massive sulfide deposits on land (e.g., Fouquet et al. 1993). Detailed geophysical, geomorphological, geological, mineralogical, geochemical and microbiological analyses of seafloor 


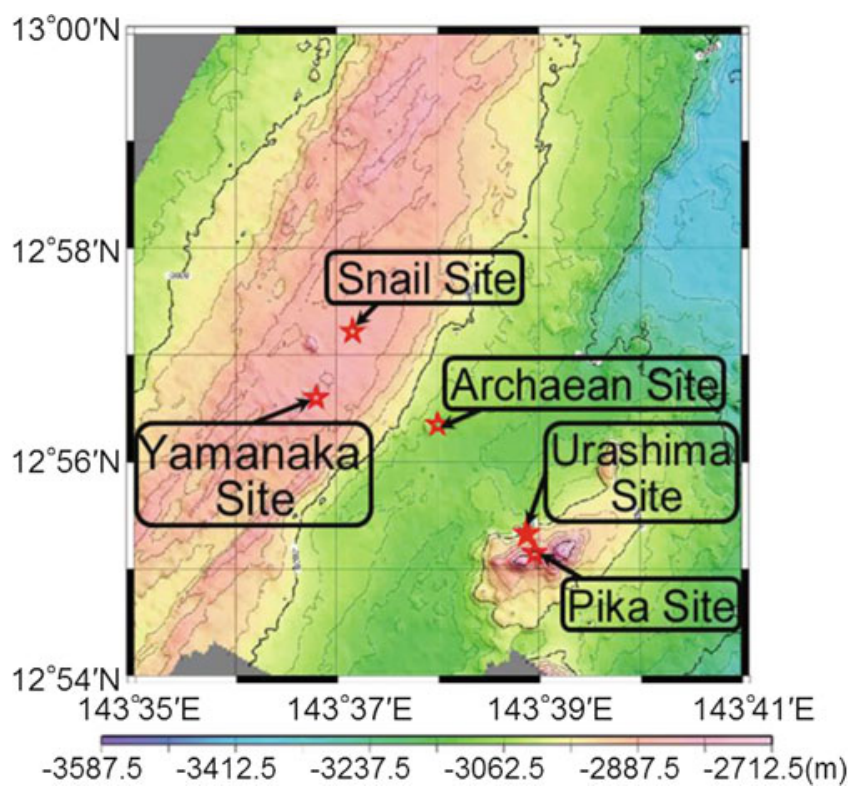

Fig. 22.1 Location of active hydrothermal vent sites on and around the backarc spreading center of the Southern Mariana Trough. The Snail and Yamanaka sites are located on the backarc spreading center (on-axis). The Archaean site is on the flank of the backarc spreading ridge. The Pika and Urashima sites are on an off-axis knoll (volcano). Contours indicate water depth in meter

hydrothermal systems in the Southern Mariana Trough have been carried out within the past 20 years (e.g., Fryer 1995; Ishibashi and Urabe 1995; Ishibashi et al. 2006; Kakegawa et al. 2008; Kato et al. 2009; Yoshikawa et al. 2012; Nakamura et al. 2013; Takamasa et al. 2013; Ishibashi et al. Chap. 23). In this area, five active hydrothermal fields lie in three different geological environments (Fig. 22.1). The Snail and Yamanaka sites are located on the crest of the backarc-spreading ridge (on-axis), while the Pika and Urashima sites are on an off-axis knoll (volcano). The Archaean site lies on the flank of the backarc spreading ridge. The linear array of hydrothermal activities at Snail, Archaean and Pika sites which is almost perpendicular to the arc trend may be related to a structural lineament, although there is no visible tectonic feature connecting them in this area. Yoshikawa et al. (2012) investigated the five hydrothermal sites using near-bottom swath mapping data by the autonomous underwater vehicle URASHIMA and dive observation data by the submersible SHINKAI 6500. They indicated that the two on-axis sites (Snail and Yamanaka) represent locations of local activity associated with a 4th order spreading segment-scale diking event, in contrast, the three off-axis sites (Archaean, Pika and Urashima) represent locations of sustained large-scale hydrothermal activity related to an off-axis upwelling magma system. Previous studies reported that sulfur isotopic ratios of sulfide minerals are different between on-axis and off-axis sites in the Southern Mariana Trough (Ishibashi et al. 2006; Kakegawa et al. 2008).
In this study, we conducted further detailed descriptions of mineral and chemical compositions in hydrothermal minerals from the Snail, Yamanaka, Archaean and Pika sites to evaluate the geochemical characteristics between on-axis and off-axis seafloor hydrothermal mineralizations.

\subsection{Samples}

From 2003 to 2005, mineralized samples were collected from the Southern Mariana Trough by submersible diving and shallow drilling. Sample localities are shown in Figs. 22.1, 22.2, 22.3, and 22.4.

Sampling at the Snail site was conducted during YK03-09 cruise. Sulfide crusts (sample \#788-1 and \#794-3) seen around the hydrothermal discharge were collected. The sample (\#788-1) is a piece of hard sulfide crusts with $3-5 \mathrm{~cm}$ thickness, showing porous texture. Exterior surface has a thin oxidized layer (Fig. 22.5a). An inactive chimney was sampled from the Yamanaka site during TN167A cruise. The sample (\#774-7) has a central conduit and has wall 2-3 cm thick (Fig. 22.5b). From the Archaean site, active and inactive chimneys and massive sulfide breccias were sampled during TN167A and YK05-09 cruises. Samples (\#903-2 and \#903-4) of active chimneys were obtained from orifice and body of $343{ }^{\circ} \mathrm{C}$ black smoker chimney (Fig. 22.5c). Inactive chimneys (sample \#903-6) were sampled from the top of a sulfide mound accompanying shimmering of low-temperature fluids. Sample \#903-7 is a large flange structure that has many spires on its surface (Fig. 22.5d). Three massive sulfide breccias (sample \#9031, \#903-5 and \#774-10) were collected from surface of sulfide mounds, which are considered as parts of relict chimneys (Fig. 22.5e). Mineralized samples from the Pika site were collected during YK05-09 and BMS 2004 cruises, and can be categorized in three groups: active chimney, massive sulfide breccia, and drill core. An active chimney sample was obtained from $<60{ }^{\circ} \mathrm{C}$ clear smoker vent. The sample (\#906-2) has tubular structure filled with later sulfides (Fig. 22.5f). Massive sulfide breccias (sample \#906-1, \#906-3, \#906-4 and \#906-5) were sampled from bottom and top of the sulfide mound. The samples are characterized by dominance of coarse-grained pyrite (Fig. 22.5g). During BMS 2004 cruise, shallow drilling by BMS (Benthic Multi-coring System, JOGMEC) was performed at the margin of the Pika mound (APM02; Fig. 22.4a). The APM02 hole (subbottom depth $=5.6 \mathrm{~m}$ ) is entirely composed of massive sulfides beneath thin manganese oxide cover, although recovery of the core was $14 \%$. Four fragments were subsampled from the APM02 core (Fig. 22.5h). 


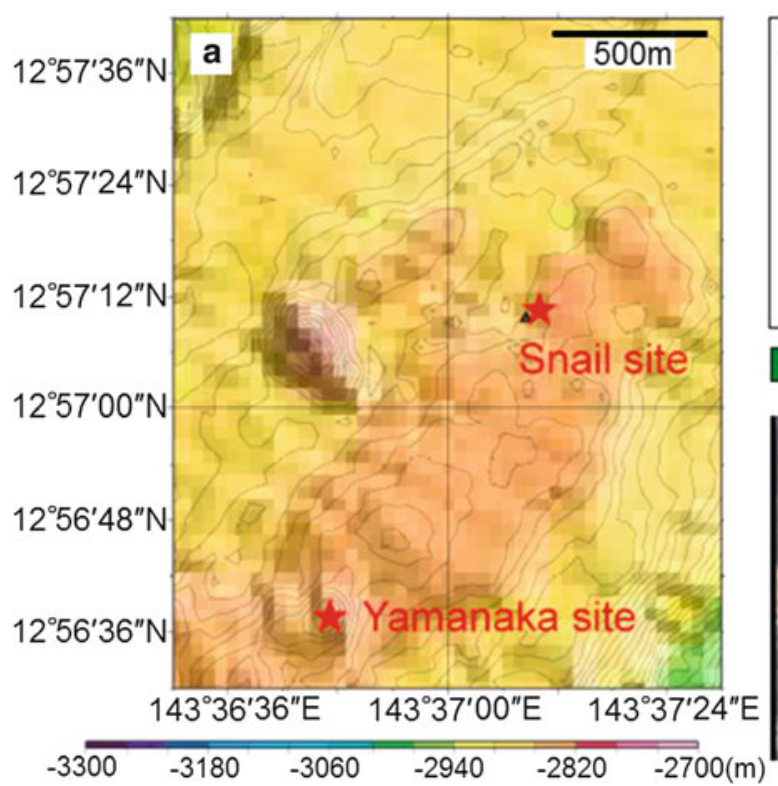

Fig. 22.2 Hydrothermal activity at the Snail and Yamanaka sites. (a) Bathymetric map of the crest of the backarc spreading ridge, showing locations of the Snail and Yamanaka sites. Contours indicate water depth in meter. (b) Distribution of hydrothermal activity of the Snail site is modified after the Cruise Report of YK03-09. Blue stars indicate the sampling points of hydrothermal mineralization. Number in degrees Celsius is the maximum temperature of the discharging fluid. (c) Hydrothermal discharge through a crack of hydrothermal
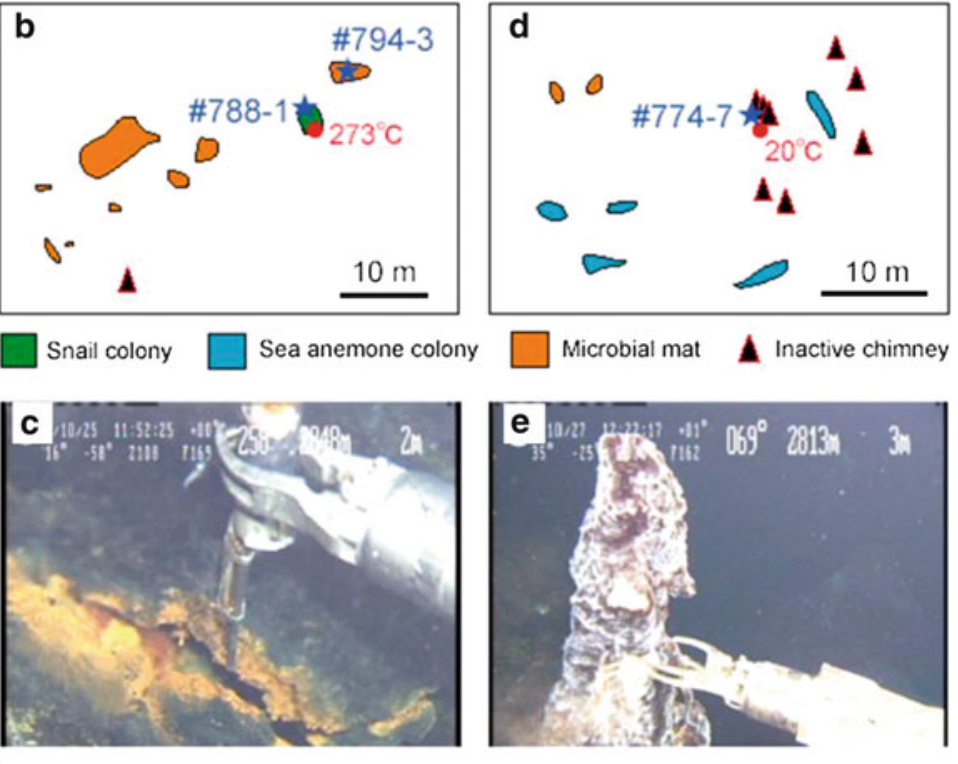

sulfide crust at the Snail site. The yellowish material lined along the crack is microbial mat. Width of view is $\sim 50 \mathrm{~cm}$. (d) Distribution of hydrothermal activity of the Yamanaka site is modified after the Cruise Report of YK03-09. Blue star indicates the sampling point of hydrothermal mineralization. Number in degrees Celsius is the maximum temperature of the discharging fluid. (e) Inactive chimney covered by whitish microbial mat observed at the Yamanaka site. Width of view is $\sim 1 \mathrm{~m}$
Fig. 22.3 Hydrothermal activity at the Archaean site. (a) Bathymetry and distribution of hydrothermal activity of the Archaean site constructed from video logs of the dive \#903 during the YK05-09. Contours indicate water depth in meter. Numbers in degrees Celsius are the maximum temperatures of the discharging fluids. Blue stars indicate the sampling points of hydrothermal mineralization. (b) Large flange structure seen at the middle part of the Archaean Colossal. Width of view is $\sim 3 \mathrm{~m}$. (c) Actively hydrothermal venting at the $343{ }^{\circ} \mathrm{C}$ black smoker chimney. Width of view is $\sim 50 \mathrm{~cm}$. (d) Shimmering of $93{ }^{\circ} \mathrm{C}$ hydrothermal fluids from the sulfide mound. Width of view is $\sim 3 \mathrm{~m}$
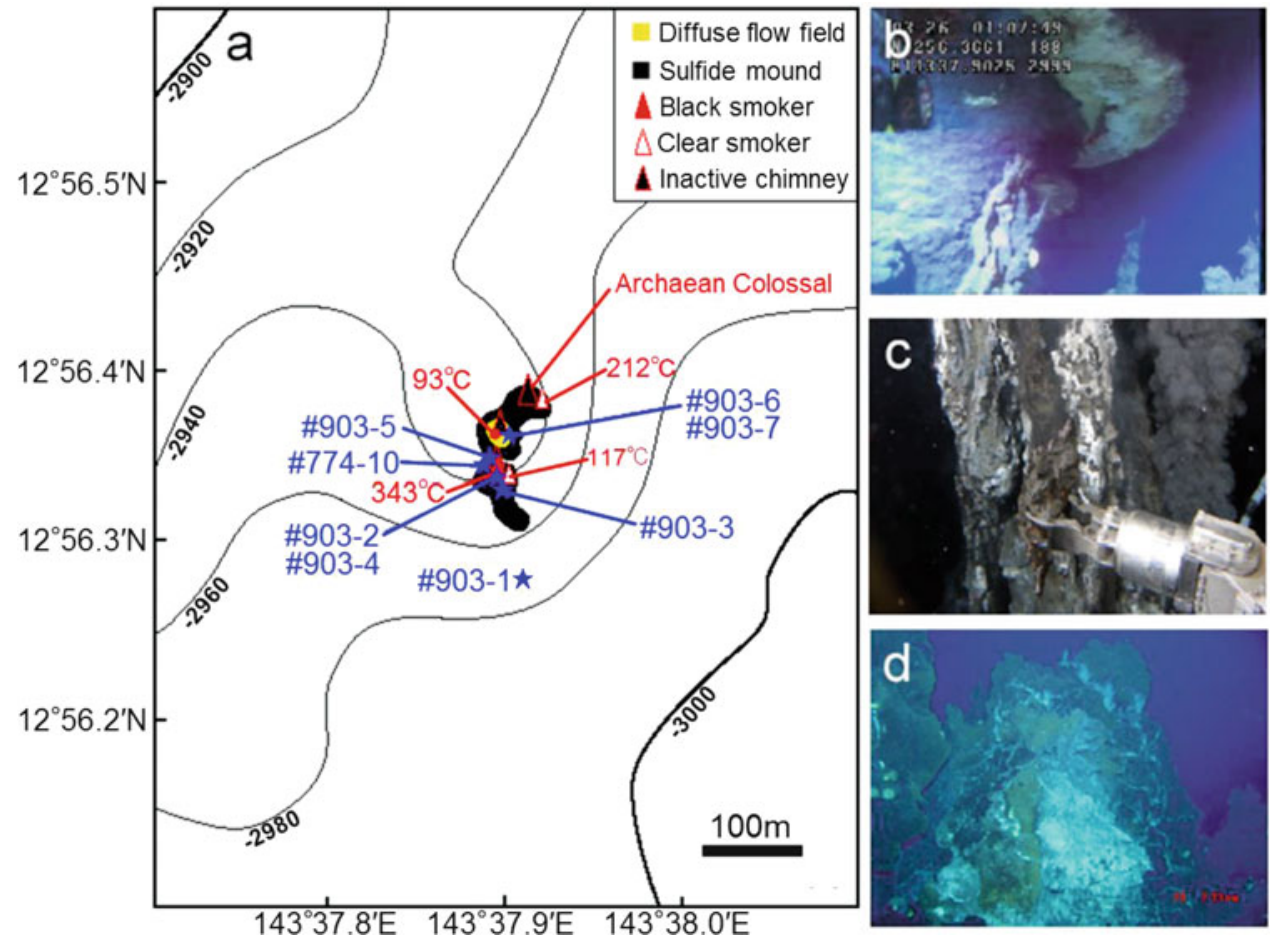


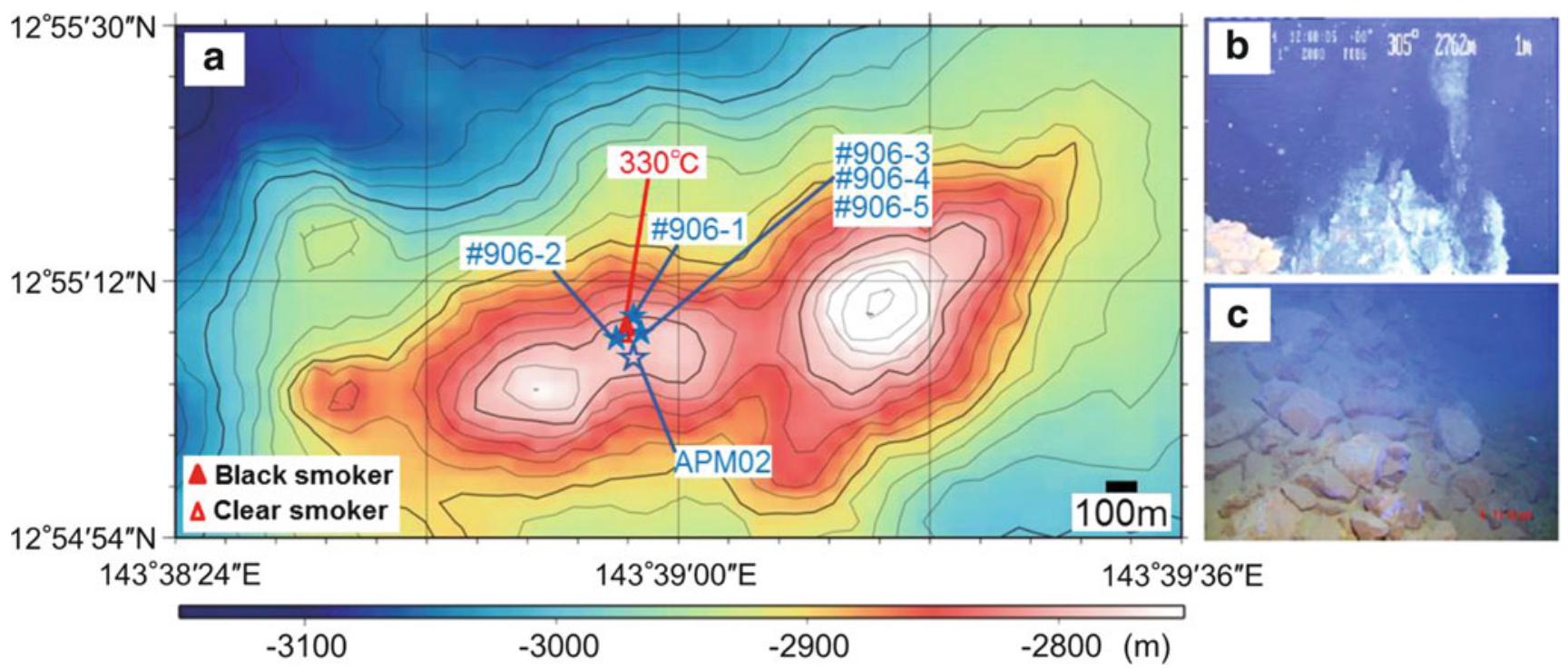

Fig. 22.4 Hydrothermal activity at the Pika site. (a) Bathymetry and distribution of hydrothermal activity of the Pika site (modified after the Cruise Report of YK03-09). Contours indicate water depth in meter. Number in degrees Celsius is the maximum temperature of the discharging fluids. Solid blue stars indicate the sampling points of

\subsection{Analytical Methods}

\subsubsection{Electron Probe X-ray Microanalysis}

Chemical compositions of sulfide minerals were determined on a JEOL JCXA-733 electron probe X-ray microanalyzer at Kyushu University, using the thin sections for microscopy after dried in an oven $\left(\sim 80{ }^{\circ} \mathrm{C}\right)$ overnight and coated with evaporated carbon film. This instrument operates with a $20 \mathrm{kV}$ acceleration voltage and a $10 \mathrm{nA}$ specimen current.

\subsubsection{Geochemistry of Hydrothermal Ores}

Mineralized sample was subsampled (10-50 g), washed with deionized water, dried in air overnight, and ground to powder in an agate mortar. About $0.5 \mathrm{~g}$ of the powder sample was decomposed with $20 \mathrm{~mL}$ conc. $\mathrm{HNO}_{3}$ and $2 \mathrm{~mL} 31 \%$ $\mathrm{H}_{2} \mathrm{O}_{2}$ on a hot plate with a temperature of about $80^{\circ} \mathrm{C}$. Soon after evaporated to dryness, the precipitates were dissolved in $10 \mathrm{~mL} 5 \mathrm{~N} \mathrm{HNO}_{3}$. The solution was diluted to proper concentration and conditioned to $1 \mathrm{~N} \mathrm{HNO}_{3}$. Analyses were performed using a Shimadzu AA-680 atomic absorption/ flame emission spectrophotometer at Kyushu University.

\subsubsection{Fluid Inclusion Microthermometry}

Doubly polished thick sections of sphalerite, barite, anhydrite and gypsum were prepared for fluid inclusion study. hydrothermal mineralization. Open blue star indicates the position of the drill hole APM02 by BMS. (b) Several black smokers at the top of the sulfide mound. Width of view is $\sim 3 \mathrm{~m}$. (c) Piles of massive sulfide breccias and sulfide debris seen at the bottom of the Pika mound. Width of view is $\sim 2 \mathrm{~m}$

Microthermometric measurements of fluid inclusions were performed under near infrared (IR) light using Olympus BX51-IR1. Heating and freezing were run using Linkam TH-600, calibrated using synthetic fluid inclusions.

\subsubsection{Sulfur Isotope Measurement}

Sulfur isotopic compositions of sulfide and barite samples were measured at the University of Tokyo using a Thermo Finnigan DELTAplus mass spectrometer. To prepare $\mathrm{SO}_{2}$ for mass spectrometry, thermal decomposition of $\mathrm{BaSO}_{4}$ with $\mathrm{V}_{2} \mathrm{O}_{5}$ and $\mathrm{SiO}_{2}$ described by Yanagisawa and Sakai (1983) was employed. Sulfur isotopic compositions are reported as $\delta^{34} \mathrm{~S}$ notation relative to CDT (Canyon Diablo Troilite).

\subsection{Results and Discussion}

\subsubsection{Mineralogy, Fluid Inclusion Microthermometry and Mineral Parageneses}

Sulfide crust samples from the Snail site show moderately zoned texture from interior to exterior. The inner layer is enriched in colloform marcasite with minor amount of pyrite overgrowing barite. Small blebs of chalcopyrite are rarely seen. The intermediate layer, which occupies large part of the crust, consists of predominant sphalerite, common marcasite, barite and amorphous silica, and minor pyrite, 
Fig. 22.5 Sample photographs of typical mineralization from the Southern Mariana Trough. (a) Sulfide crust from the Snail site (sample \#788-1). The upper side is the surface of the crust. (b) Cross cut of an inactive chimney sampled from the Yamanaka site (sample \#774-7). Chalcopyrite lines the central conduit. (c) Piece of active chimney from the Archaean site (sample \#903-2). The upper side is the exterior surface. (d) Large inactive flange structure collected from the Archaean site (sample \#903-7). The inset is a cross cut of a spire grown on the surface of the flange structure. The conduit is filled with barite (white) and $\mathrm{Fe}$ oxides (brown). (e) Massive sulfide breccia found on the hydrothermal mound of the Archaean site (sample \#903-1). (f) Cross cut of an active chimney sampled from the Pika site (sample \#906-2). (g) Massive sulfide breccia from the Pika mound (sample \#906-4). The inset is a surface texture characterized by occurrence of millimetric pyritohedrons. (h) Drill core sample APM02-22 collected from beneath the Pika mound. Scale bar in each photograph is $1 \mathrm{~cm}$ except that Figs. $22.5 \mathrm{a}, \mathrm{b}, \mathrm{h}$ are $5 \mathrm{~mm}$
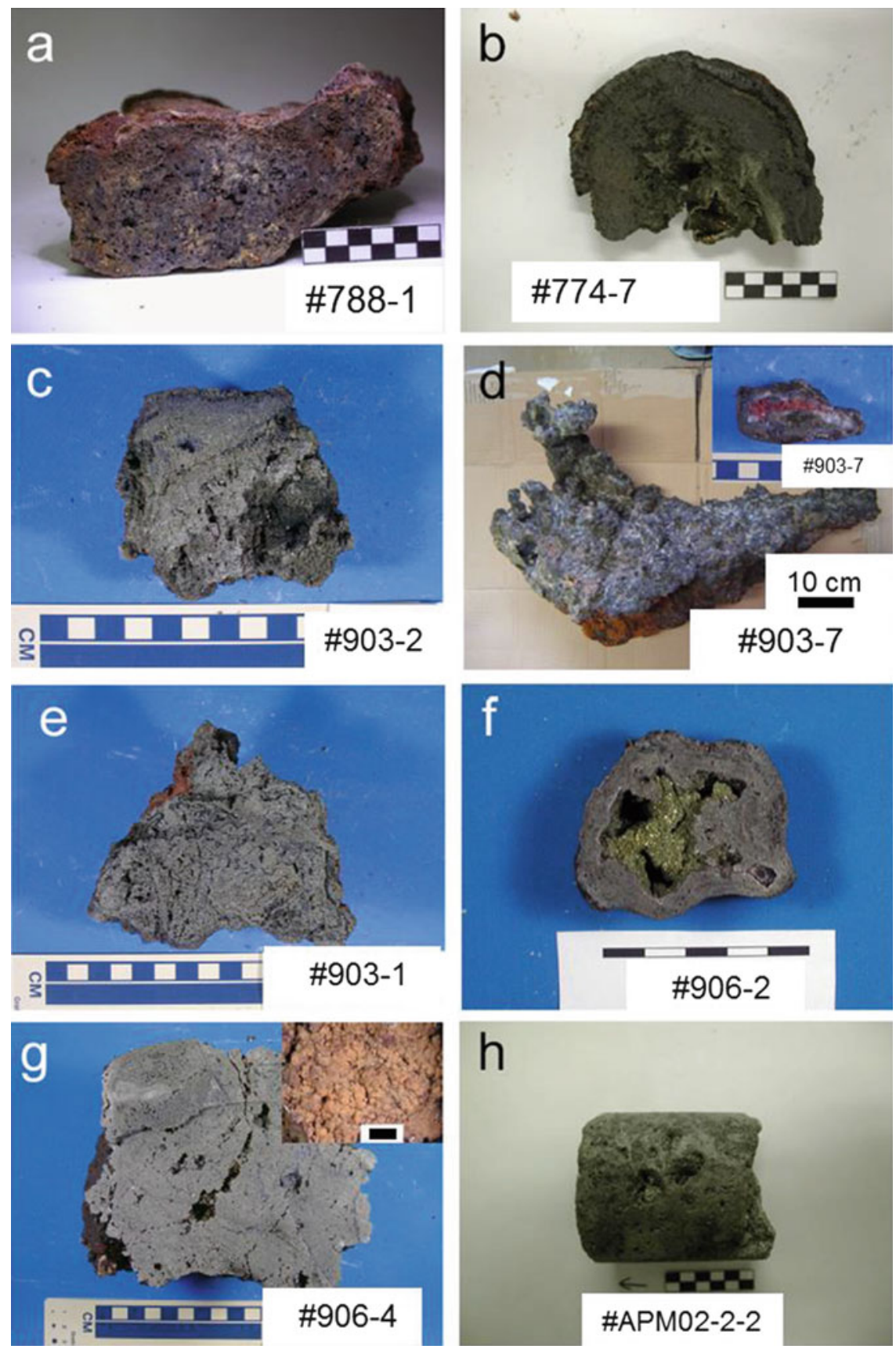

chalcopyrite, galena and tennantite. Sphalerite contains small inclusions of chalcopyrite, galena and tennantite (Fig. 22.6a). Galena and tennantite are common in seafloor hydrothermal minerals on arc and backarc environments (Herzig et al. 2002). Marcasite and pyrite occur as blebs in sphalerite and barite. Some early barite was replaced by sulfides such as sphalerite and marcasite, and some late barite cuts sphalerite, marcasite and pyrite. Yet much of barite appears to be precipitated contemporary with sulfide mineralization. The outermost zone is composed of finegrained barite with little sulfides. Sulfides and barite are mantled by amorphous silica.
Paragenetic sequence for mineralization at the Snail site is shown in Fig. 22.7a. Fine-grained barite is the first mineral to precipitate. At a higher temperature, small blebs of marcasite and sphalerite are associated with barite (stage I). An isotopic equilibrium temperature (cf., Sect. 22.4.4) of $224{ }^{\circ} \mathrm{C}$ was obtained for the mineral assemblage marcasite and sphalerite of the stage I. A ratio of sulfides and barite and crystallinity of sulfides increase with increasing temperature, and replacement of sphalerite by tennantite and chalcopyrite occurs (stage II). Precipitation of galena is confined to the stage II, suggesting that galena is precipitated at a higher temperature. A sphalerite-hosted fluid inclusion from stage 
Fig. 22.6 Reflected light photomicrographs of typical mineral assemblages from the Southern Mariana Trough. (a) Sphalerite contains chalcopyrite and galena as inclusions seen in sample \#788-1. (b) Assemblage of sphalerite, chalcopyrite and marcasite seen in sample \#774-7. Chalcopyrite disease is frequently found (see lower left of the photomicrograph). (c)

Intermediate solid solution associated with sphalerite, chalcopyrite and pyrite seen in sample \#903-2. (d) Typical mineral assemblage seen in inactive chimney from the Archaean site. Marcasite is mantled by sphalerite, which is in turn mantled by jordanite (sample \#903-6). (e) Typical mineral assemblage seen in massive sulfide breccias from the Archaean site (sample \#903-1). Sphalerite and chalcopyrite is partly replaced by marcasite, and later barite overgrows sulfides. (f) Zonation of marcasite, sphalerite and chalcopyrite seen in sample \#906-2. (g) Photomicrograph of massive sulfide breccia (sample \#906-4). No sulfide mineral is found other than pyrite. (h) Photomicrograph of sample APM02-2-2. The sample consists only of pyrite, but more porous and less mature texture than the massive sulfide breccia samples from the mound (cf., Fig. 22.6g). Scale bar in each

photomicrograph is $100 \mu \mathrm{m}$. bar barite, $c p$ chalcopyrite, $g n$ galena, iss intermediate solid solution, $j d$ jordanite, $m c$ marcasite, $p y$ pyrite, $s p$ sphalerite
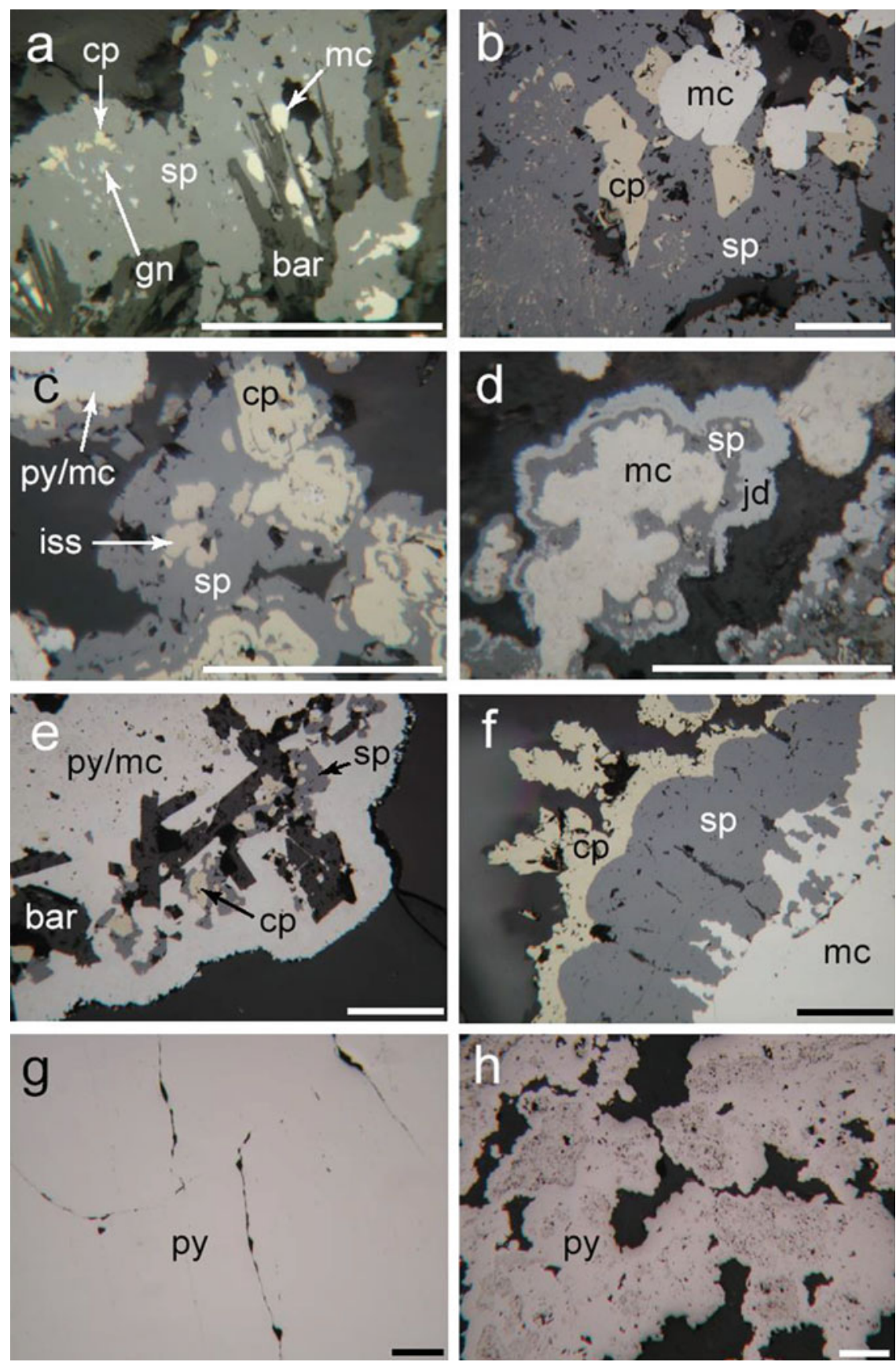

II mineralization yielded trapping temperature of $261{ }^{\circ} \mathrm{C}$, which is about $10^{\circ} \mathrm{C}$ lower than maximum vent fluid temperature recorded in May 2003. At the waning stage, barite is precipitated in open spaces as relatively coarse crystals. These barites have fluid inclusions with trapping temperatures 188 and $200{ }^{\circ} \mathrm{C}$. Amorphous silica fills the interstices of sulfides and barite at the last (stage III).

Inactive chimney collected from the Yamanaka site is enriched in sphalerite, marcasite and chalcopyrite. Marcasite and lesser amount of pyrite frequently form dendritic and/or colloform aggregates. Pyrite in the inner wall occasionally exhibits cubic morphology. Chalcopyrite disease (Barton and Bethke 1987) in sphalerite is common (Fig. 22.6b). Wurtzite is identified under transmitted polarized light using its anisotropy. Lining of chalcopyrite, which replaces sphalerite, is predominant along central conduit. The exterior surface has a thin layer composed of marcasite, pyrite, sphalerite and barite, which would be formed by fluid seepage through the chimney body.

Paragenetic sequence for mineralization at the Yamanaka site is shown in Fig. 22.7b. Fine-grained barite and dendritic and/or framboidal marcasite are the first mineral assemblage to precipitate, followed by precipitation of sphalerite, marcasite, pyrite and chalcopyrite (stage I). Wurtzite, which can 
a Snail

\begin{tabular}{l|c|ccc|c|}
\hline Temperature $\left({ }^{\circ} \mathrm{C}\right)$ & 200 & 250 & 270 & 200 & 160 \\
\hline Stage & 1 & & II & & III \\
\hline Barite & & & & & \\
Marcasite & & & & & \\
Pyrite & & & & \\
Sphalerite & & & & \\
Chalcopyrite & & & & \\
Tennantite & & & & \\
Galena & & & & \\
Amor. silica & & & & \\
\hline
\end{tabular}

\section{c Archaean}

\begin{tabular}{|c|c|c|c|c|c|}
\hline Temperature $\left({ }^{\circ} \mathrm{C}\right)$ & $270 \quad 326$ & 340 & 340 & 3002 & 00130 \\
\hline Stage & 1 & II & III & IV & $\mathrm{v}$ \\
\hline Anhydrite & & & & & \\
\hline Barite & & & & & \\
\hline Marcasite & & & & & \\
\hline Pyrite & & & & & \\
\hline Sphalerite & & & & & \\
\hline Chalcopyrite & & & & & \\
\hline & & - & & & \\
\hline Tennantite & & & & - & \\
\hline Jordanite & & & & - & \\
\hline Chalcocite & & & & - & \\
\hline Covellite & & & & - & \\
\hline
\end{tabular}

\section{b Yamanaka}

\begin{tabular}{l|c|c|c|}
\hline Temperature $\left({ }^{\circ} \mathrm{C}\right)$ & 250 & $250 \quad 200$ \\
\hline Stage & I & II & III \\
\hline Barite & & & \\
Marcasite & & & \\
Pyrite & & & \\
Sphalerite & & & \\
Wurtzite & & & \\
Chalcopyrite & & & \\
\hline
\end{tabular}

Fig. 22.7 Paragenetic sequence of hydrothermal mineralization in the Southern Mariana Trough. (a) Snail site; (b) Yamanaka site; (c) Archaean site; (d) Pika site. Iss intermediate solid solution, Amor. silica amorphous silica

be precipitated by rapid cooling of hydrothermal fluids as a metastable phase, would be associated with relatively early mineralization. An isotopic equilibrium temperature (cf., Sect. 22.4.4) of $306{ }^{\circ} \mathrm{C}$ was obtained for the assemblage pyrite/marcasite and sphalerite. This temperature is about $50{ }^{\circ} \mathrm{C}$ higher than a trapping temperature of sphaleritehosted fluid inclusion $\left(256{ }^{\circ} \mathrm{C}\right)$, but may be closer to the maximum temperature of mineralization at the Yamanaka site. Much of chalcopyrite in the Yamanaka sample extensively replaces sphalerite and marcasite/pyrite (stage II). Reactions for the replacement would be written as follows (Ohmoto 1996):

$$
\begin{aligned}
& 2 \mathrm{ZnS}(\mathrm{s})+\mathrm{H}^{+}+\mathrm{Cu}^{+}+\mathrm{Fe}^{2+} \\
& \quad=\mathrm{CuFeS}_{2}(\mathrm{~s})+2 \mathrm{Zn}^{2+}+1 / 2 \mathrm{H}_{2}(\mathrm{aq})
\end{aligned}
$$

\begin{tabular}{|c|c|c|c|}
\hline Temperature $\left({ }^{\circ} \mathrm{C}\right)$ & 290 & 330 & $320 \quad 220$ \\
\hline Stage & 1 & II & III \\
\hline Anhydrite & & & \\
\hline Gypsum & & & \\
\hline Barite & - & & - \\
\hline Marcasite & & & \\
\hline Pyrite & & & \\
\hline Sphalerite & & & \\
\hline Chalcopyrite & & & \\
\hline Jordanite & 一 & & \\
\hline
\end{tabular}

d Pika

These reactions can take place when hydrothermal fluid is undersaturated with respect to sphalerite but saturated with respect to chalcopyrite. These conditions would be satisfied by increase in temperature of the hydrothermal fluid. Smaller amounts of marcasite, pyrite, sphalerite and barite would be precipitated at the waning stage (stage III).

Active chimneys from the base of $343{ }^{\circ} \mathrm{C}$ black smoker at the Archaean site consist of abundant pyrite and marcasite, common sphalerite and chalcopyrite, and minor barite, iss (intermediate solid solution), tennantite, jordanite, chalcocite and covellite. Intermediate solid solution is associated with sphalerite, chalcopyrite and pyrite (Fig. 22.6c). 
Tennantite and jordanite occur locally as tiny blebs in sphalerite. Barite occurs only in outermost part of the chimney, where colloform marcasite is predominant. The inner part has abundant pyrite and chalcopyrite, and lacks marcasite. Anhydrite-hosted fluid inclusions from the $343{ }^{\circ} \mathrm{C}$ vent orifice have trapping temperatures ranging from 276 to $349^{\circ} \mathrm{C}$. This temperature range can be explained by precipitation mechanism of anhydrite by mixing of vent fluids with seawater. Salinities of these inclusions have a wide range between 3.2 and $5.4 \mathrm{wt} \% \mathrm{NaCl}$. Inactive chimneys from the Archaean mounds contain abundant marcasite, common pyrite, sphalerite and barite, and minor tennantite and jordanite. Marcasite and pyrite occur as cryptocrystalline or colloform aggregates. Sphalerite mantles colloform marcasite, and the sphalerite is in turn mantled by jordanite (Fig. 22.6d). Much of barite occurs as late-stage infillings of conduits and interstices. Massive sulfide rubbles from the Archaean mound are predominated by cryptocrystalline pyrite and marcasite with lesser amounts of sphalerite, chalcopyrite and barite, which are relatively simple mineralogy. Pyrite and marcasite intimately coexist and seem to have replaced much of sphalerite and chalcopyrite. Tabular barite is precipitated within interstices of sulfides and even replacing sulfides (Fig. 22.6e). Chalcocite and covellite occur as secondary minerals.

Mineralization from the Archaean site has five paragenetic successions (Fig. 22.7c). Anhydrite disseminated with pyrite, sphalerite and chalcopyrite is the first mineral assemblage to precipitate from black smoker fluids (stage I). According to the maturity of the chimney, sulfide mineralization involving pyrite, marcasite, sphalerite and chalcopyrite becomes predominant (stage II). Here, iss is precipitated at a temperature higher than $340{ }^{\circ} \mathrm{C}$. Sphalerite precipitated under such a high-temperature condition. Replacement of sphalerite and pyrite/marcasite by chalcopyrite (reactions 1 and 2) would also occur at the Archaean site. However, resulting chalcopyrite would be, in turn, replaced by pyrite/ marcasite by the following reaction (Ohmoto 1996):

$$
\begin{aligned}
2 \mathrm{CuFeS}_{2}(\mathrm{~s})+4 \mathrm{H}^{+}= & 2 \mathrm{Cu}^{+}+\mathrm{Fe}^{2+} \\
& +\mathrm{FeS}_{2}(\mathrm{~s})+2 \mathrm{H}_{2} \mathrm{~S}(\mathrm{aq})
\end{aligned}
$$

High-temperature acidic hydrothermal fluids undersaturated with chalcopyrite can drive this reaction. The product $\mathrm{H}_{2} \mathrm{~S}$ can cause direct precipitation of pyrite/marcasite by the following reaction (Ohmoto 1996):

$$
\mathrm{Fe}^{2+}+2 \mathrm{H}_{2} \mathrm{~S}(\mathrm{aq})=\mathrm{FeS}_{2}(\mathrm{~s})+2 \mathrm{H}^{+}+\mathrm{H}_{2}(\mathrm{aq})
$$

Much of the assemblage sphalerite + pyrite/marcasite + chalcopyrite is consequently replaced by pyrite/marcasite by the reactions 3 and 4 (stage III). At the waning stage, sphalerite (trapping temperature $=300{ }^{\circ} \mathrm{C}$ ) is the predominant mineral to precipitate with accessory minerals such as tennantite and jordanite. Barite is the last mineral to precipitate under a temperature between 208 and $130{ }^{\circ} \mathrm{C}$ (salinities $=3.2-5.2 \mathrm{wt} \% \mathrm{NaCl}$ ).

Active chimney sampled from the Pika site consists of abundant cryptocrystalline marcasite and pyrite, common sphalerite and chalcopyrite, and rare jordanite and barite. Zonation of marcasite/pyrite, sphalerite and chalcopyrite is well developed (Fig. 22.6f). Massive sulfide breccias from the Pika mound are composed of coarse-grained euhedral pyrite so called pyritohedrons, which coalesce each other to form massive pyrite breccia (Fig. 22.6g). Cryptocrystalline texture of pyrite is rarely seen, and no sulfide phase other than pyrite is recognized. Cracks within massive sulfide breccias are locally filled with gypsum and lesser amount of anhydrite. A thin rind of Fe-oxides and sulfate is also found on their exterior. Fluid inclusions in anhydrite filling cracks of massive sulfides yielded trapping temperature ranges between 306 and $328^{\circ} \mathrm{C}$ for primary inclusions and 232 and $278{ }^{\circ} \mathrm{C}$ for secondary inclusions. Trapping temperatures of primary inclusions are mostly within a range between 320 and $330^{\circ} \mathrm{C}$, which is well consistent with a maximum vent fluid temperature. The primary inclusions hosted by anhydrite yielded a wide salinity range between 3.5 and $5.4 \mathrm{wt} \% \mathrm{NaCl}$, while the secondary inclusions yielded salinities from 4.2 to $4.3 \mathrm{wt} \%$ $\mathrm{NaCl}$. Pyrite is an only component of drill core samples recovered from the APM02 hole at the Pika site. Pyrite of these samples is characterized by cryptocrystalline texture (Fig. 22.6h), which can be recognized as formed under relatively low-temperature conditions (e.g., Ramdohr 1980). In addition, these core samples represent relatively porous texture.

Figure $22.7 \mathrm{~d}$ shows the mineral paragenesis for the Pika mineralization. Barite, marcasite, pyrite, chalcopyrite and sphalerite (trapping temperatures $=291$ and $296{ }^{\circ} \mathrm{C}$ ) with accessory jordanite are the early sulfide phases (stage I). Replacement of sphalerite by the reaction 1 is common in this stage. At the main stage of mineralization, sphalerite and chalcopyrite are significantly replaced by pyrite by the reaction 3 (stage II). When the chimney composed of massive pyrite is cracked, anhydrite is precipitated to fill the cracks. Subsequently, anhydrite is hydrated by ambient seawater to form gypsum, followed by precipitation of barite at the waning stage (stage III).

\subsubsection{Characteristics of Chemical Compositions for Selected Minerals}

The FeS contents in sphalerite grains from the Southern Mariana Trough are shown in Fig. 22.8. Sphalerite from the Snail site has a narrow range of FeS contents between 
Fig. 22.8 Histograms of FeS content in sphalerite from the Southern Mariana Trough. (a) Snail site; (b) Yamanaka site; (c) Archaean site; (d) Pika site
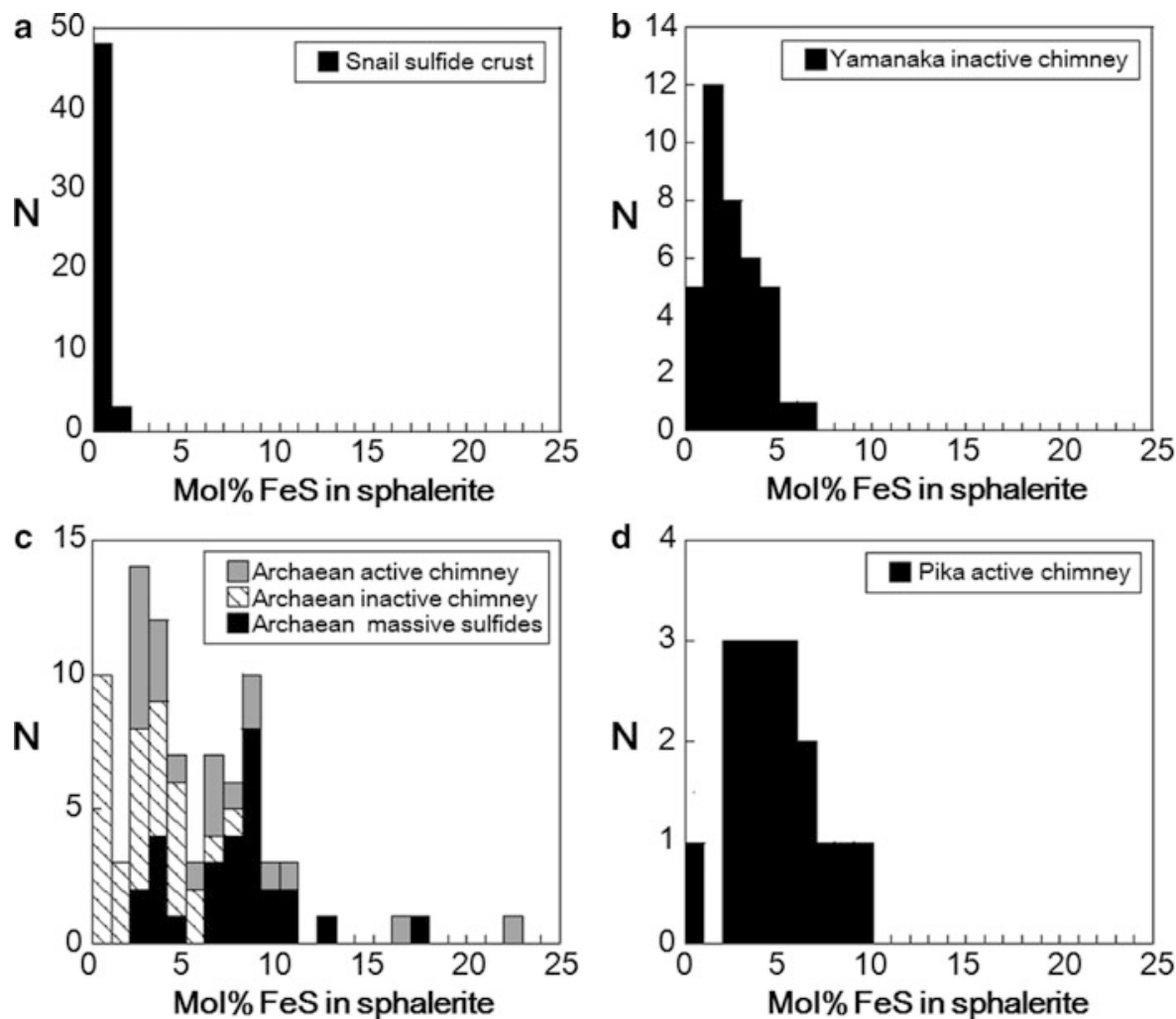

nil and 1.8 , and $0.4 \mathrm{~mol} \%$ on average. FeS contents in sphalerite/wurtzite from the Yamanaka site range between 0.3 and $6.9 \mathrm{~mol} \%$, averaging $2.5 \mathrm{~mol} \%$. On the other hand, sphalerite from the off-axial sites has wider ranges of $\mathrm{FeS}$ contents. Sphalerite in active chimneys from the Archaean site contains 2.2-22.5 mol\% FeS and has average FeS content of $6.5 \mathrm{~mol} \%$. Sphalerite in inactive chimneys has FeS contents ranging from nil to 7.3 , and $2.7 \mathrm{~mol} \%$ on average. Sphalerite in massive sulfide breccias contains $2.0-17.3 \mathrm{~mol}$ $\% \mathrm{FeS}$ and has average $\mathrm{FeS}$ contents of $7.5 \mathrm{~mol} \%$. For sphalerite from the Pika site, FeS contents have a range between 0.8 and $9.1 \mathrm{~mol} \%$ and an average value of $4.8 \mathrm{~mol} \%$.

The sulfur fugacity $\left(\mathrm{f}_{\mathrm{S} 2}\right)$ of hydrothermal fluids for each site was determined using the FeS content in sphalerite and a formation temperature of the sphalerite (Scott and Barnes 1971). The calculated $f_{S 2}$ of hydrothermal systems in the Southern Mariana Trough is low for off-axial sites and high for on-axial sites. The mineralizations from the Archaean and Pika sites yielded lower $\mathrm{f}_{\mathrm{S} 2}$, plotted near the equilibrium between pyrite and pyrrhotite. In sediment-free mid-ocean ridge systems, the pyrite-pyrrhotite buffer controls the $\mathrm{f}_{\mathrm{S} 2}$ condition (e.g., Hannington et al. 1995). The Snail site is plotted near the sulfidation equilibrium between tennantite and enargite. Compared with the Snail site, the Yamanaka site shows a slightly lower $\mathrm{f}_{\mathrm{S} 2}$, although higher than those of off-axial sites. High $\mathrm{f}_{\mathrm{S} 2}$ condition in a hydrothermal system hosted by an arc volcano can be indicative of contribution of magmatic $\mathrm{SO}_{2}$ that disproportionates and generates $\mathrm{H}_{2} \mathrm{~S}$ (de Ronde et al. 2005).
Trace metal contents in pyrite/marcasite differ by locality and sample type. Pyrite/marcasite from the Snail and Yamanaka sites have relatively high $\mathrm{Zn}(\sim 0.23 \mathrm{wt} \%)$ and As $(\sim 0.08 \mathrm{wt} \%)$ contents. Pyrite/marcasite in chimney and massive sulfide samples from the Archaean and Pika sites have lower $\mathrm{Zn}(\sim 0.05 \mathrm{wt} \%)$ and As $(\sim 0.03 \mathrm{wt} \%)$ contents. Copper contents in pyrite/marcasite, however, make little difference by locality and sample type. Intermediate solid solution from $343{ }^{\circ} \mathrm{C}$ black smoker at the Archaean site has chemical composition close to that of stoichiometric cubanite, and is moderately zinciferous ( 1.42 wt\%).

\subsubsection{Comparison of Bulk Chemical Compositions for Mineralized Samples}

Bulk chemical concentrations of mineralized samples are given in Table 22.1. Mineralized samples from the Snail and Yamanaka sites are relatively rich in $\mathrm{Zn}(11.9-48.2 \mathrm{wt}$ $\%)$ and poor in $\mathrm{Fe}(0.88-9.07 \mathrm{wt} \%)$. These results reflect the sphalerite-dominant mineralogy of the samples. Seafloor hydrothermal mineralization formed in island arc settings can be normally differentiated from those on mid-ocean ridges by major element geochemistry. On the $\mathrm{Cu}-\mathrm{Zn}-\mathrm{Fe}$ diagram (Fig. 22.9a), mineralizations recovered from the Snail and Yamanaka sites are plotted in the arc-setting field. On the other hand, mineralized samples from the Archaean and Pika sites are characterized by higher $\mathrm{Fe}$ concentrations (21.3-42.9 wt\%), which arise 
Table 22.1 Geochemistry of hydrothermal precipitate samples from the Southern Mariana Trough, determined by atomic absorption spectrometry

\begin{tabular}{|c|c|c|c|c|c|c|c|c|c|c|}
\hline Site & Sample & Type & $\mathrm{Fe}(\mathrm{wt} \%)$ & $\mathrm{Cu}$ & $\mathrm{Zn}$ & $\mathrm{Pb}(\mathrm{ppm})$ & $\mathrm{Mn}$ & $\mathrm{Cd}$ & $\mathrm{Sb}$ & $\mathrm{Ag}$ \\
\hline \multirow[t]{3}{*}{ Snail } & \#788-1-a & Sulfide crust (outer) & 9.07 & 0.39 & 22.7 & 5616 & 1703 & 104 & $<200$ & 98 \\
\hline & \#788-1-b & Sulfide crust (inner) & 0.88 & 0.69 & 43.3 & 3053 & 258 & 404 & $<200$ & 116 \\
\hline & $\# 794-3$ & Sulfide crust & 5.63 & 0.23 & 11.9 & 8755 & 783 & 70 & 281 & 275 \\
\hline Yamanaka & $\# 774-7$ & Inactive chimney & 8.00 & 4.90 & 48.2 & 1410 & 670 & 1288 & 284 & 74 \\
\hline \multirow[t]{7}{*}{ Archaean } & $\# 774-10$ & Massive sulfides & 42.9 & 0.88 & 0.48 & 236 & 21 & 13 & $<200$ & $<30$ \\
\hline & \#903-1 & Massive sulfides & 38.9 & 0.59 & 2.20 & 1346 & 46 & 42 & 147 & 50 \\
\hline & $\# 903-2$ & Active chimney & 33.0 & 7.51 & 0.44 & 240 & 188 & 18 & n.a. & 31 \\
\hline & $\# 903-4$ & Active chimney & 37.3 & 0.66 & 0.77 & 169 & 53 & 25 & n.a. & 32 \\
\hline & $\# 903-5$ & Massive sulfides & 37.5 & 0.03 & 0.26 & 462 & 21 & 10 & n.a. & $<30$ \\
\hline & $\# 903-6$ & Inactive chimney & 24.1 & 0.03 & 13.4 & 4997 & 1628 & 90 & n.a. & 65 \\
\hline & \#903-7 & Inactive chimney & 21.3 & 0.02 & 13.2 & 5477 & 161 & 86 & n.a. & 59 \\
\hline \multirow[t]{9}{*}{ Pika } & APM02-1-a & Drill core & 41.0 & 0.21 & 0.04 & 84 & $<20$ & $<10$ & $<200$ & $<30$ \\
\hline & APM02-2-2 & Drill core & 36.2 & 0.20 & 0.04 & 71 & $<20$ & $<10$ & $<200$ & $<30$ \\
\hline & APM02-3-1 & Drill core & 37.5 & 0.28 & 0.09 & 198 & 49 & $<10$ & $<200$ & $<30$ \\
\hline & APM02-4-1 & Drill core & 38.8 & 0.33 & 0.08 & 145 & 59 & $<10$ & $<200$ & $<30$ \\
\hline & \#906-1 & Massive sulfides & 36.1 & 0.10 & 0.03 & 77 & n.a. & $<10$ & n.a. & $<30$ \\
\hline & $\# 906-2$ & Active chimney & 32.1 & 1.78 & 5.75 & 1167 & 32 & 194 & 229 & 63 \\
\hline & \#906-3 & Massive sulfides & 34.8 & 0.02 & 0.07 & 96 & n.a. & $<10$ & $<200$ & $<30$ \\
\hline & \#906-4 & Massive sulfides & 35.5 & 0.02 & 0.08 & 90 & n.a. & $<10$ & $<200$ & $<30$ \\
\hline & \#906-5 & Massive sulfides & 36.3 & 0.03 & 0.05 & 81 & $<20$ & $<10$ & $<200$ & $<30$ \\
\hline
\end{tabular}

n.a. not analyzed
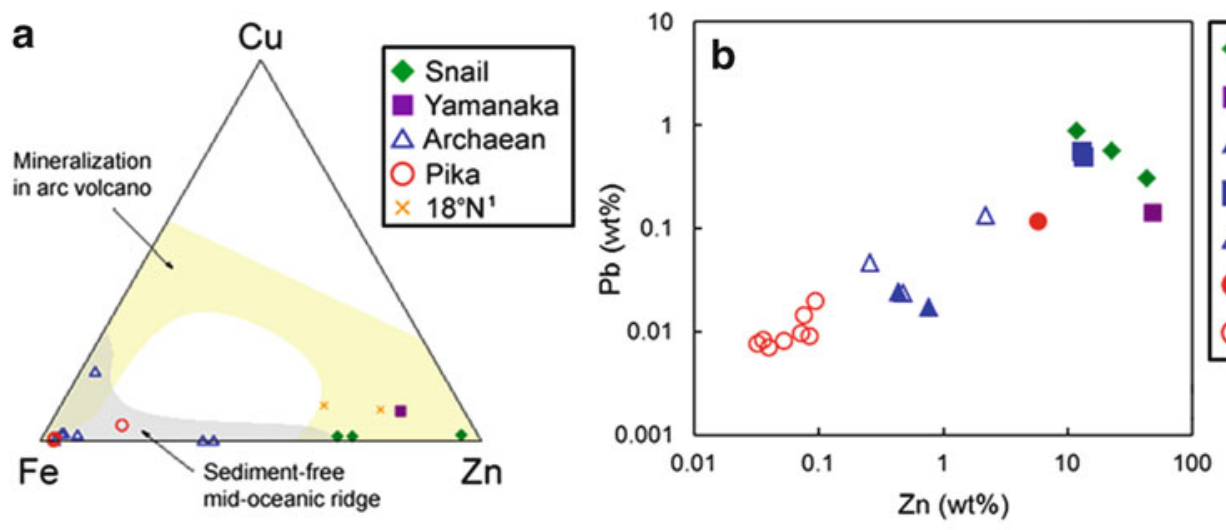

\begin{tabular}{|l|}
\hline Snail \\
Yamanaka \\
Archaean active chimney \\
Archaean inactive chimney \\
$\triangle$ Archaean massive sulfides \\
Pika active chimney \\
Pika massive sulfides \\
\hline
\end{tabular}
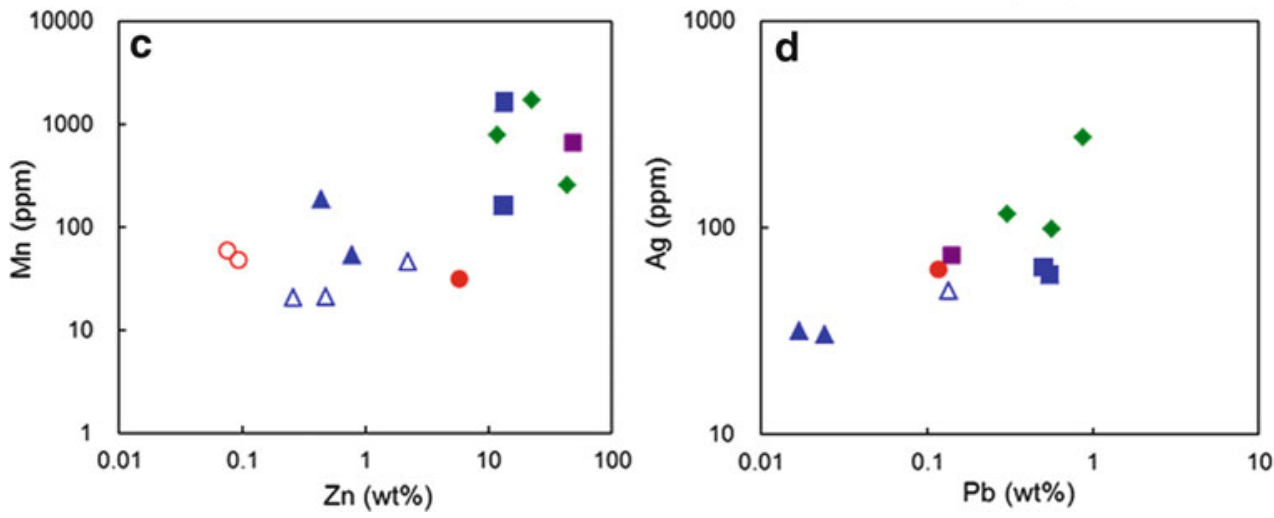

Fig. 22.9 (a) $\mathrm{Cu}-\mathrm{Fe}-\mathrm{Zn}$ ternary diagram showing the geochemistry of hydrothermal mineralization in the Southern Mariana Trough compared with those on sediment-free mid-ocean ridges (Hannington et al. 1991) and arc volcanoes (Watanabe et al. 1995; de Ronde et al. 2005). 1: Hannington (1989). (b) $\mathrm{Log} / \mathrm{log}$ plot of $\mathrm{Zn}$ versus $\mathrm{Pb}$ concentrations in precipitate samples from the Southern Mariana
Trough. Pika massive sulfides include drill core samples from the APM02 hole. (c) Log/log plot of $\mathrm{Zn}$ versus Mn concentrations in precipitate samples from the Southern Mariana Trough. Pika massive sulfides include drill core samples from the APM02 hole. (d) Log/log plot of $\mathrm{Pb}$ versus $\mathrm{Ag}$ concentrations in precipitate samples from the Southern Mariana Trough 
Fig. 22.10 Compilation of sulfur isotopic ratios $\left(\delta^{34} \mathrm{~S}_{\mathrm{CDT}} \%\right.$ o) of sulfides and sulfates from the Southern Mariana Trough compared with those from midocean ridge and island arc settings. MORB: Sakai et al. (1984); Island arc volcanic rock: Ueda and Sakai (1984); Seawater: Rees et al. (1978). a: Kakegawa et al. (2008); b: Styrt et al. (1981) and Kerridge et al. (1983)

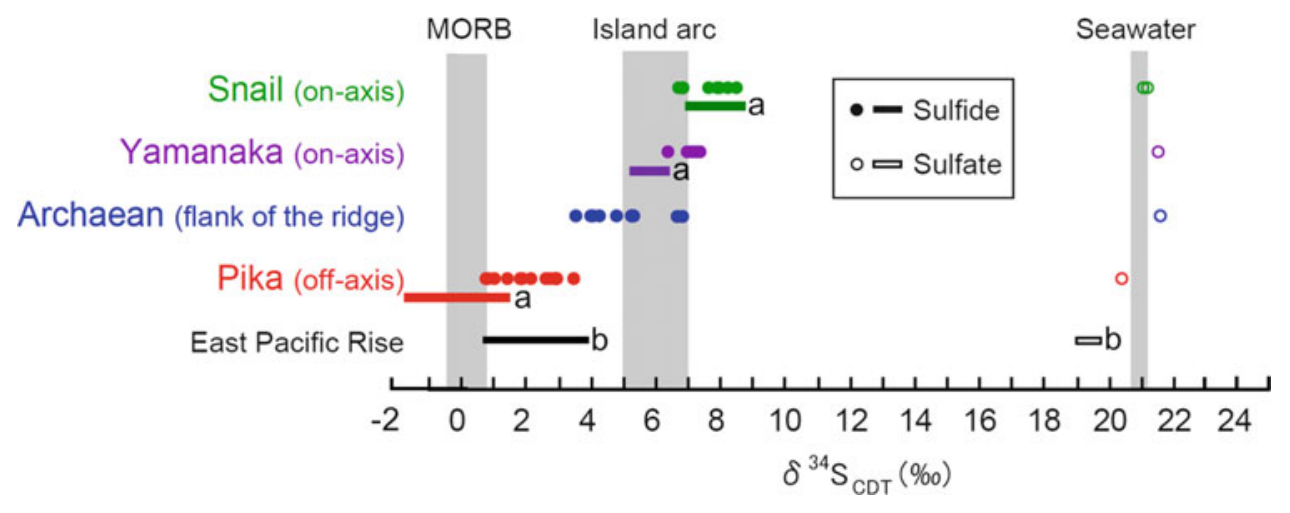

from pyrite- and marcasite-rich mineral compositions. This mineral assemblage as well as bulk chemical compositions are similar to massive pyrite ore on sediment-free mid-ocean ridges (Herzig et al. 2002) (Fig. 22.9a), although is devoid of pyrrhotite. Hydrothermal fluids from the Pika site have $\mathrm{pH}$ of 2.9 , which is somehow acid compared with the range of midocean ridge fluids (Ishibashi et al. 2006; Toki et al. Chap. 45). Therefore the solubility is enhanced and temperatures of mineral precipitation decrease, compared with those of the East Pacific Rise. As a result, pyrite is the only mineral to precipitate in high-temperature condition, and mineralization becomes enriched in Fe (Fig. 22.9a). Copper is poor in most samples $(<1 \mathrm{wt} \%)$ except for three chimney samples. The Snail and Yamanaka samples, as well as the Archaean inactive chimneys and Pika active chimney, are rich in $\mathrm{Pb}$ (1,167-8,755 ppm). Occurrence of galena and jordanite and $\mathrm{Pb}$-bearing sphalerite can account for the enrichment of $\mathrm{Pb}$ in these samples. Lead, $\mathrm{Cd}$ and $\mathrm{Mn}$ moderately to strongly correlate with Zn (Fig. 22.9b, c and Table 22.1). Samples from the Snail and Yamanaka sites have higher $\mathrm{Pb}$ and $\mathrm{Zn}$ compositions than those from the Archaean and Pika sites (Fig. 22.9b). Correlation between $\mathrm{Mn}, \mathrm{Cd}$ and $\mathrm{Zn}$ can be explained by formation of solid solution as sphalerite. But precipitation of $\mathrm{Mn}$ oxyhydroxide during the lowtemperature mineralization would contribute to $\mathrm{Mn}$ geochemistry. Correlation between $\mathrm{Pb}$ and $\mathrm{Zn}$ may be attributed to the mineralogy that sphalerite contains $\mathrm{Pb}$-bearing minerals as invisible inclusions. Silver correlates more strongly with $\mathrm{Pb}$ (Fig. 22.9d), suggesting that $\mathrm{Ag}$ is incorporated in galena.

\subsubsection{Source of a Range in Sulfur Isotopic Compositions for Sulfide and Sulfate Minerals from the Southern Mariana Trough}

The hydrothermal minerals from the Southern Mariana Trough show variable $\delta^{34} \mathrm{~S}$ values, ranging from +0.8 to $+8.5 \%$ o (Fig. 22.10). Sulfides from the Snail sulfide crust samples have $\delta^{34} \mathrm{~S}$ values between +6.8 and $+8.5 \%$ for sphalerite and between +6.9 and $+7.9 \%$ for pyrite/marcasite. These $\delta^{34} \mathrm{~S}$ ranges are consistent with the reported values $\left(\delta^{34} S=+7.0-+8.7 \%\right.$ ) for sulfide crust samples from the Snail site (Kakegawa et al. 2008). Inner parts of the samples have lower $\delta^{34} \mathrm{~S}$ values than the outer parts. An equilibrium temperature of $224{ }^{\circ} \mathrm{C}$ is calculated using the sphalerite-pyrite fractionation equation of Smith et al. (1977). Sulfides from the Yamanaka inactive chimney have $\delta^{34} \mathrm{~S}$ values between +7.1 and $+7.4 \%$ for sphalerite, between +7.0 and $7.2 \%$ for chalcopyrite and $+6.4 \%$ for pyrite/marcasite. These $\delta^{34} \mathrm{~S}$ ranges are slightly higher than those $\left(\delta^{34} \mathrm{~S}=+5.1-+6.3 \%\right.$ o) for sulfide chimney samples from the Yamanaka site (Kakegawa et al. 2008). Sulfides from the inner wall of chimney have lower $\delta^{34} \mathrm{~S}$ values than those from the outer wall. The pyrite-sphalerite geothermometer yields $306{ }^{\circ} \mathrm{C}$ for pyrite/marcasitesphalerite assemblage. Sulfides from the Archaean site yielded $\delta^{34} \mathrm{~S}$ values ranging from +4.1 to $+4.3 \%$ for sphalerite and from +3.6 to $+6.9 \%$ for pyrite/marcasite. Sulfides from the Pika site have $\delta^{34} \mathrm{~S}$ values between +0.8 and $+3.5 \%$ for pyrite/marcasite and $+1.0 \%$ for sphalerite. These $\delta^{34} \mathrm{~S}$ ranges are slightly higher than those $\left(\delta^{34} \mathrm{~S}=-1.8-+1.7\right.$ $\%$ ) for sulfide chimney samples from the Pika site (Kakegawa et al. 2008). Sulfur isotope ratios of drill core samples $\left(\delta^{34} \mathrm{~S}=+2.8-+3.5 \%\right)$ are slightly higher than those of massive sulfide samples $\left(\delta^{34} \mathrm{~S}=+1.4-+3.0 \%\right.$ ). Barites from the Southern Mariana Trough $\left(\delta^{34} S=+20.4\right.$ $-+21.6 \%$ ) are isotopically close to seawater sulfate, indicating that mixing of hydrothermal fluids with seawater brought about barite precipitation. The fact that $\delta^{34} \mathrm{~S}$ value (+20.4\%) of the Pika barite is slightly lower than that of the ambient seawater indicates mixing of hydrothermal fluids with a small amount of seawater and subsequent oxidation of hydrothermal sulfide. Sulfides from the on-axial sites (Snail and Yamanaka) obviously have higher $\delta^{34} S$ values than those from the off-axial site (Pika). In addition, $\delta^{34} \mathrm{~S}$ values of sulfides from the Archaean site, which is situated between the Snail and Pika sites, are approximately intermediate between those of the Snail and Pika sites. 
There can be several processes that cause isotopic fractionation and develop a wide range in $\delta^{34} \mathrm{~S}$ values within a single hydrothermal field. It is possible that higher $\delta^{34} \mathrm{~S}$ values obtained from the Snail and Yamanaka sulfides are attributed to the incorporation of seawater sulfate-derived sulfur without isotopic fractionation during reducing process in a seafloor environment. Sulfur occurs as sulfate in seawater with $\delta^{34} \mathrm{~S}$ values of about $+21 \%$ (Rees et al. 1978). So the incorporation of seawater sulfate-derived sulfur reduced without isotope fractionation can increase the $\delta^{34} \mathrm{~S}$ values. However, the theoretical modeling shows that mixing of hydrothermal fluids with seawater at the seafloor cannot generate $\delta^{34} \mathrm{~S}$ value heavier than $+4.5 \%$ o (Janecky and Shanks 1988). Thus, this process cannot explain the range in the $\delta^{34} \mathrm{~S}$ values of the Snail and Yamanaka sites. Around seafloor hydrothermal sites, heating $\left(150-200{ }^{\circ} \mathrm{C}\right)$ of seawater during downflow in upper oceanic crust commonly results in the formation of anhydrite (Shanks et al. 1981; Janecky and Shanks 1988). At high-temperature conditions of above $200{ }^{\circ} \mathrm{C}$, the anhydrite $\left(\mathrm{SO}_{4}{ }^{2-}\right)$ is subsequently dissolved, and partially reduced to sulfide $\left(\mathrm{H}_{2} \mathrm{~S}\right)$ without isotope fractionation (Shanks et al. 1981; Shanks and Seyfried 1987). Therefore, the degree of mixing of this isotopically heavy sulfur with magmatic sulfur can account for the variation of $\delta^{34} \mathrm{~S}$ values of sulfide minerals in the four hydrothermal sites. The other possible cause of the sulfur isotopic range is the variety in the $\delta^{34} \mathrm{~S}$ values of the host rocks under each vent site. The incorporation of sulfur into hydrothermal fluids by leaching of igneous sulfides proceeds with little isotopic fractionation, therefore the fluid $\mathrm{H}_{2} \mathrm{~S}$ should have $\delta^{34} \mathrm{~S}$ values similar to footwall rock values (Shanks et al. 1995). The $\delta^{34} \mathrm{~S}$ values of mid-ocean ridge basalt (MORB) vary within a narrow range of $+0.1 \pm 0.5 \%$ o (Sakai et al. 1984). In contrast, island arc magma has higher $\delta^{34} \mathrm{~S}$ values of up to $+7 \%$ due to the presence of a subduction-related seawater sulfate component in the subarc mantle source (Ueda and Sakai 1984). The $\delta^{34} \mathrm{~S}$ values of backarc magma lie between those of MORB and island arc rocks (Alt et al. 1993). In the Southern Mariana Trough, the close proximity of arc volcanoes to the spreading center may be responsible for the axial high of the spreading center. The proximity, as well as the radial faulting pattern of the eastern backarc basin south of $13^{\circ} 10^{\prime} \mathrm{N}$, may facilitate channeling of arc magma to the spreading center (Fryer 1995; Fryer et al. 1998). Martinez et al. (2000) proposed that the welldeveloped spreading system, in contrast to the rifting-stage system of the Northern Mariana Trough, channels arc magma efficiently along the backarc-spreading axis. They also suggested that the small arc seamounts in the Southern Mariana Trough may also support the derivation of the arc magmatic budget to the spreading center. Although there are no sulfur isotopic data of footwall volcanic rocks from the Snail, Yamanaka, Archaean and Pika sites, basement rocks from the four hydrothermal fields have geochemical signatures of slab-derived components (Nakamura et al., Chap. 41). Moreover, our data show that mineralizations from the on-axial sites tend to have an arc-like geochemical signatures compared with those from the off-axial sites. Therefore, at the moment, we cannot rule out the possibility that the sulfur isotope variations of sulfide minerals from the four hydrothermal sites are influenced by sulfur isotopic characteristics of volcanic rocks under each vent site.

Acknowledgments We wish to thank SHINKAI 6500 and ROV ROPOS team members, crews of the $\mathrm{R} / \mathrm{V}$ YOKOSUKA and $\mathrm{R} / \mathrm{V}$ Thomas $G$. Thompson, and onboard scientists for their skillful support during the YK03-09, YK05-09 and TN167A cruises. We also thank crews of the R/V Hakurei-Maru No.2 during the BMS2004 cruise for their cooperation. Profs. Hitoshi Chiba and Shunichi Nakai are thanked for their constructive comments that helped improve the manuscript. This study was supported by the Ministry of Education, Culture, Sports, Science and Technology (MEXT) of Japan through a Special Coordination Fund "Archaean Park Project" and a Grant-in-Aid for Scientific Research on Innovative Areas "TAIGA project". This study was also financially supported by JSPS and NSF, respectively.

Open Access This chapter is distributed under the terms of the Creative Commons Attribution Noncommercial License, which permits any noncommercial use, distribution, and reproduction in any medium, provided the original author(s) and source are credited.

\section{References}

Alt JC, Shanks WC III, Jackson MC (1993) Cycling of sulfur in subduction zones: the geochemistry of sulfur in the Mariana island arc and back-arc Trough. Earth Planet Sci Lett 119:477-494

Barton PB, Bethke PM (1987) Chalcopyrite disease in sphalerite: pathology and epidemiology. Am Mineral 72:451-467

de Ronde CEJ, Hannington MD, Stoffers P, Wright IC, Ditchburn RG, Reyes AG, Baker ET, Massoth GJ, Lupton JE, Walker SL, Greene RR, Soong CW, Ishibashi J, Lebon GT, Bray CJ, Resing JA (2005) Evolution of a submarine magmatic-hydrothermal system: Brothers volcano, southern Kermadec arc, New Zealand. Econ Geol 100:1097-1133

Fouquet Y, von Stackelberg U, Charlou JL, Erzinger J, Herzig PM, Mühe R, Wiedicke M (1993) Metallogenesis in back-arc environments; the Lau Basin example. Econ Geol 88:2154-2181

Fryer P (1995) Geology of the Mariana Trough. In: Taylor B (ed) Backarc basins: tectonics and magmatism. Springer, New York, pp 237-279

Fryer P, Fujimoto H, Sekine M, Johnson LE, Kasahara J, Masuda H, Gamo T, Ishii T, Ariyoshi M, Fujioka K (1998) Volcanoes of the southwestern extension of the active Mariana island arc: new swathmapping and geochemical studies. Island Arc 7:596-607

Hannington MD (1989) The geochemistry of gold in modern sea-floor hydrothermal systems and implications for gold mineralization in ancient volcanogenic massive sulfides, $\mathrm{PhD}$ thesis, University of Toronto, p 554

Hannington MD, Herzig PM, Scott SD, Thompson G, Rona P (1991) Comparative mineralogy and geochemistry of gold-bearing sulfide deposits on the mid-ocean ridges. Mar Geol 101:217-248

Hannington MD, Jonasson IR, Herzing PM, Petersen S (1995) Physical and chemical processes of seafloor mineralization at mid-ocean ridges. In: Humphris SE, Zierenberg RA, Mullineaux LS, 
Thomson RE (eds) Seafloor hydrothermal systems: physical, chemical, biological, and geological interactions. Geophysical monograph series, vol 91, Am Geol Union, pp 115-157

Herzig PM, Hannington MD (1995) Polymetallic massive sulfides at the modern seafloor: a review. Ore Geol Rev 10:95-115

Herzig PM, Hannington MD, Petersen S (2002) Polymetallic massive sulphide deposits at the modern seafloor and their resource potential. In: Polymetallic massive sulphides and cobalt-rich ferromanganese crusts: status and prospects, international seabed authority technical study 2, Report on the UN Workshop on Seafloor Mineral Resources 2000, Kingston, Jamaica, pp 8-35

Ishibashi J, Urabe T (1995) Hydrothermal activity related to arcbackarc magmatism in the Western Pacific. In: Taylor B (ed) Tectonics and magmatism. Plenum Press, New York, pp 451-495

Ishibashi J, Suzuki R, Yamanaka A, Toki T, Kimura H, Noguchi T, Urabe T (2006) Seafloor hydrothermal activity at off-axial seamounts of backarc spreading in Southern Mariana Trough. Geochim Cosmochim Acta 70:A279

Janecky DR, Shanks WC III (1988) Computational modeling of chemical and sulfur isotopic reaction processes in seafloor hydrothermal systems: chimney, massive sulfides, and subjacent alteration zones. Can Mineral 26:805-825

Kakegawa T, Utsumi M, Marumo K (2008) Geochemistry of sulfide chimneys and Basement pillow lavas at the Southern Mariana Trough $\left(12.55^{\circ} \mathrm{N}-12.58^{\circ} \mathrm{N}\right)$. Res Geol 58:249-266

Kato S, Kobayashi C, Kakegawa T, Yamagishi A (2009) Microbial communities in iron-silica-rich microbial mats at deep-sea hydrothermal fields of the Southern Mariana Trough. Environ Microbiol 11:2094-2111

Kerridge JF, Haymon RM, Kastner M (1983) Sulfur isotope systematics at the $21^{\circ} \mathrm{N}$ site, East Pacific Rise. Earth Planet Sci Lett 66:91-100

Martinez F, Fryer P, Becker N (2000) Geophysical characteristics of the Southern Mariana Trough, $11^{\circ} 50^{\prime} \mathrm{N}-13^{\circ} 40^{\prime} \mathrm{N}$. J Geophys Res 105:16591-16607

Nakamura K, Toki T, Mochizuki N, Asada M, Ishibashi J, Nogi Y, Yoshikawa S, Miyazaki J, Okino K (2013) Discovery of a new hydrothermal vent based on an underwater, high-resolution geophysical survey. Deep Sea Res I 74:1-10

Ohmoto H (1996) Formation of volcanogenic massive sulfide deposits: the Kuroko perspective. Ore Geol Rev 10:135-177

Ramdohr P (1980) The ore minerals and their intergrowth. Pergamon Press, Oxford, p 1205

Rees CE, Jenkins WJ, Monster J (1978) The sulfur isotopic composition of ocean water sulfate. Geochim Cosmochim Acta 42:377-381
Sakai H, Des Maris DJ, Ueda A, Moore JG (1984) Concentrations and isotope ratios of carbon, nitrogen, and sulfur in ocean-floor basalts and volcanic gases at Kilauea volcano, Hawaii. Geochim Cosmochim Acta 48:2433-2441

Scott SD, Barnes HL (1971) Sphalerite geothermometry and geobarometry. Econ Geol 66:653-669

Shanks WC III, Böhlke JK, Seal RR II (1995) Stable isotopes in midocean ridge hydrothermal systems: interactions between fluids, minerals and organisms. In: Humphris SE, Zierenberg RA, Mullineaux LS, Thomson RE (eds) Seafloor hydrothermal systems: physical, chemical, biological, and geological interactions. Geophysical monograph series, vol 91, Am Geol Union, pp 194-221

Shanks WC III, Seyfried WE Jr (1987) Stable isotope studies of vent fluids and chimney minerals, southern Juan de Fuca Ridge. Sodium metasomatism and seawater sulfate reduction. J Geophys Res 92:11387-11399

Shanks WC III, Bischoff JL, Rosenbauer RJ (1981) Seawater sulfate reduction and sulfur isotope fractionation in basaltic systems: interaction of seawater with fayalite and magnetite at $200-350{ }^{\circ} \mathrm{C}$. Geochim Cosmochim Acta 45:1977-1995

Smith JW, Doolan S, McFarlane EF (1977) A sulfur isotope geothermometer for the trisulfide system galena-sphalerite-pyrite. Chem Geol 19:83-90

Styrt MM, Brackmann AJ, Holland HD, Clark BC, Pisutha-Arnond V, Eldridge CS, Ohmoto H (1981) The mineralogy and the isotopic composition of sulfur in hydrothermal sulfide/sulfate deposits on the East Pacific Rise, $21^{\circ} \mathrm{N}$ latitude. Earth Planet Sci Lett 53:382-390

Takamasa A, Nakai S, Sato F, Toyoda S, Banerjee D, Ishibashi J (2013) U-Th radioactive disequilibrium and ESR dating of a baritecontaining sulfide crust from South Mariana Trough. Quart Geochron 15:38-46

Ueda A, Sakai H (1984) Sulfur isotope study of Quaternary volcanic rocks from the Japanese island arc. Geochim Cosmochim Acta 48:1837-1848

Watanabe K, Shibata A, Kajimura T (1995) Comparison of the bulk chemical composition between hydrothermal sulfides from Suiyo Seamount and sea-floor hydrothermal sulfides from the other areas. JAMSTEC J Deep Sea Res 11:351-361

Yanagisawa F, Sakai H (1983) Thermal decomposition of barium sulfate-vanadium pentaoxide-silica glass mixtures for preparation of sulfur dioxide in sulfur isotope ratio measurements. Anal Chem 55:985-987

Yoshikawa S, Okino K, Asada M (2012) Geomorphological variations at hydrothermal sites in the Southern Mariana Trough: relationship between hydrothermal activity and topographic characteristics. Mar Geol 303-306:172-182 